\title{
可塑性油脂の結晶転移の研究に対する一方法
}

\author{
須 見 恵 二*・阿 部 芳 郎** \\ * 鐘渻化学工業株式会社 (兵庫県高砂市高砂町宮前) \\ ** 慶応大学工学部（東京都小金井市前原町 4-794）
}

\section{One Method of Studying on the Crystal Transformation of Plastic Fats}

Keiji Sumi* and Yoshirō Abe**

* Kanegafuchi-Kagaku-Kōgyō Co. Ltd., (Takasago-shi, Hyōgo-ken)

** Faculty of Engineering, Keiō University (Koganei-shi, Tokyo)

Studies on the crystal structure of many pure triglycerides by means of X-ray diffraction have been made by several researchers but on polymorphic crystal transformation of triglycerides, especially on fats, many problems are left.

Authors made researches in crystal transformation of plastic fats such as tallow, hydrogenated fish oil, binary system of tallow and hydrogenated fish oil, and cocoa butter by X-ray diffraction.

Based on the nomenclature by C.W. Hoerr, authors identified four crystal forms $\alpha, \beta^{\prime}$ (beta prime), intermediate and $\beta$.

As tallow and hydrogenated fish oil take the crystal structure of $\beta^{\prime}$ and intermediate form, it is possible to determine the approximate proportion of $\beta^{\prime}$ form by comparing the intensity of diffraction band at $3.8 \mathrm{~A}$ which is peculiar. As regards cocoa butter it takes $\alpha$ and $\beta$ form, and the $\alpha$ directly transforms to $\beta$.

The proportion of $\beta$ form, therefore, can be determined in similar manner.

Authors graphically presented the relation between transformation of polymorph and tempering of the plastic fats within 240 minutes.

\section{1 緒言}

グリセリドのポリモリフィズムの研究は, 油脂の基礎 物性を究明するらえにますます重要視されてきている。 X線解析によるグリセリドの結晶構造の研究は, E.S. Lutton $^{1,2)}$, T. Malkin ${ }^{3)}$ らによって種々の単一グリセ リドについて行なわれてきた。E.S. Lutton は,グリセ リドの結晶構造には, $\alpha, \beta^{\prime}, \beta-2, \beta^{\prime}-3, \beta-3$ の多形が存 在するとしているが, T. Malkin らは, $\alpha, \beta^{\prime \prime}, \beta^{\prime}, \beta$ の多形に分けている。一方 C.W. Hoerr ${ }^{4), 5)}$ は, $\alpha, \beta^{\prime}$, intermediate, $\beta$, の多形に分けるのが妥当であるとし て, それらの回折線図を確認している。単一トリグリセ リド, 混合飽和トリグリセリド, 不飽和酸を含むトリグ リセリドの長面間隔, 短面間隔が, C.E. Clarkson ${ }^{6}$, T. Malkin ${ }^{7,8)}$, E.S. Lutton ${ }^{9), 10)}$ らによって詳細に報告 されている。飽和トリグリセリドの場合は，長面間隔か ら結晶の傾きが計算され結晶の判定基準となってい る ${ }^{11)}$ 。さらに脂肪, ショートニングなどのような複雑な 組成を有する混合グリセリドの X 線解析 ${ }^{5), 12) ~ 14)}$ 亿関し ても報告がされている。
著者らは, 結晶形の異なる牛脂, 硬化魚油, カカオ脂 などの食用油脂およびそれらを配合することにより各種 の可塑性油脂を調製し, 結晶構造について検討を行な い，ついで配合の転移速度に及ぼす影響について考察を 行なった。

著者らはグリセリドの結晶構造として，C.W. Hoerr の提唱した多形にならい， $\alpha, \beta^{\prime}$, intermediate, $\beta$ の多 形を用い，結晶転移の様子をグラフ的に表示した。なお 転移速度を測る一つの試みとして，それぞれの結晶形に 特有の回折線に注目して, その強度を比較することによ って固体脂中の各結晶形の割合を求め, その変化から転 移速度を求めた。

\section{2 実験}

$2 \cdot 1$ 実 験 操 作

使用したX線装置は，理学電機製 D-2 L 型 X 線回折 装置である。試料を充てんしたガラス製試料板は，厚さ $2 \mathrm{~mm}$ のもを用いた。X 線回折に際して測定条件は Table-1 のようにした。

$2 \cdot 2$ 試 料 油 
Table-1 Operating conditions of X-ray analysis.

\begin{tabular}{ll|l}
\hline & & Short Spacings \\
\hline Target & & $\mathrm{CuK}_{\alpha}$ \\
Divergency & slit & $1^{\circ}$ or $1 / 6^{\circ}$ \\
Scatter & slit & $1^{\circ}$ \\
Receiving & slit & $0.1 \mathrm{~mm}$ \\
Scale & factor & 16 or 8 \\
Time & const. & 4 \\
Scanning & speed & $1 / 2 \% \mathrm{~min}$ \\
Chart & speed & $1 \mathrm{~cm} / \mathrm{min}$ \\
\hline
\end{tabular}

牛脂, 硬化魚油, その配合油は, $30 \mathrm{~g}$ 取り, いったん $80^{\circ} \mathrm{C}$ 程度に融解し, $0^{\circ} \mathrm{C}$ の水水中で急冷固化する。乳 バチの周囲を研水で泠却しつつ, 乳バチ中で $10 \mathrm{~min} よ$ く練り,さらに乳バチを常温までもどしつつ充分に練っ たもの(ネッ和)を試料に用いた。これらの性状は，3・3 の項に示す。カカオ脂, シア脂, パーム油は市販精製油 を用いた。

\section{3 結果}

\section{$3 \cdot 1$ 牛脂の各結晶型の $X$ 線回折図}

グリセリドの示す同質多形に関しては, 各研究者によ ってその表示法が異なり，これら異なった結晶型の特徴 は, X線回折図に㧍いて短面間隔および長面間隔の差で 表われることが知られている。著者らはHoerr に従っ $\tau$, 牛脂を試料に用いて $\alpha, \beta^{\prime}$, intermediate, $\beta$ 型の各 結晶を調製しX線回折図を求めた。各結晶形の特徵は, 短面間隔でよく示されるので結晶型の判定には短面間隔 を使用した。各結晶の調製法を略記するとつぎのように なる。

$\alpha$ 型 牛脂を $80^{\circ} \mathrm{C}$ 程度まで加温融解し, 試料板をあ らかじめ $-10^{\circ} \mathrm{C}$ まで下がった氷食塩水中で泠 却しつつ，牛脂を急冷固化する。

$\beta^{\prime}$ 型 (beta prime 型) 牛脂を融解後, 室温 $20^{\circ} \mathrm{C}$ 付 近において徐冷する。一昼夜放置を行なら。

intermediate 型 牛脂を $2 \cdot 2$ 項のように処理し（ネ ツ和) $30^{\circ} \mathrm{C}$ にコントロールされた 恒温器中で 一週間テンパリングを行なう。

Operating condition of $\mathrm{X}$-ray;

Slit $1 / 6-1-0.1$

Scale fac. 8

Time const. 4

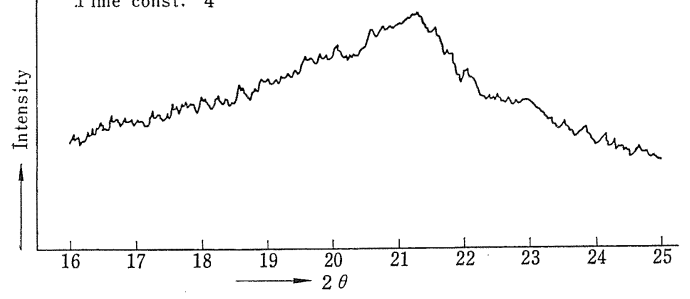

Fig.-1 X-ray diffraction pattern of tallow $(\alpha)$ from petreum ether.

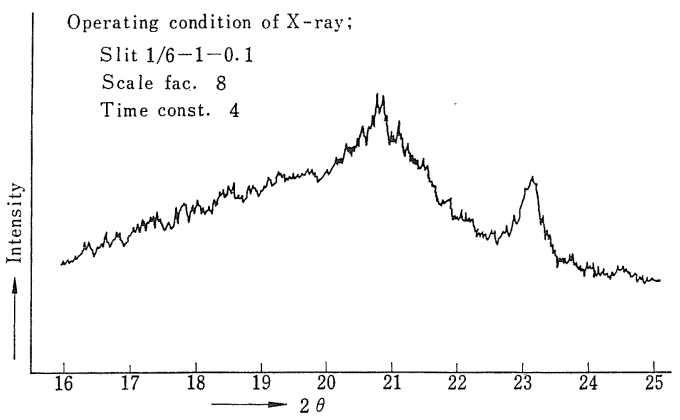

Fig.-2 X-ray diffraction pattern of tallow $\left(\beta^{\prime}\right)$.

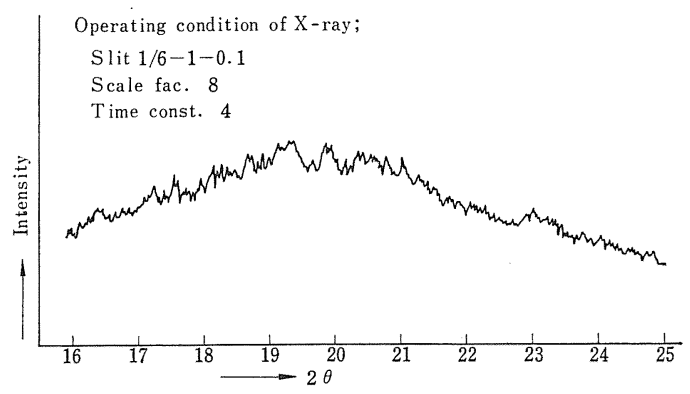

Fig.-3 X-ray diffraction pattern of tallow (intermediate).

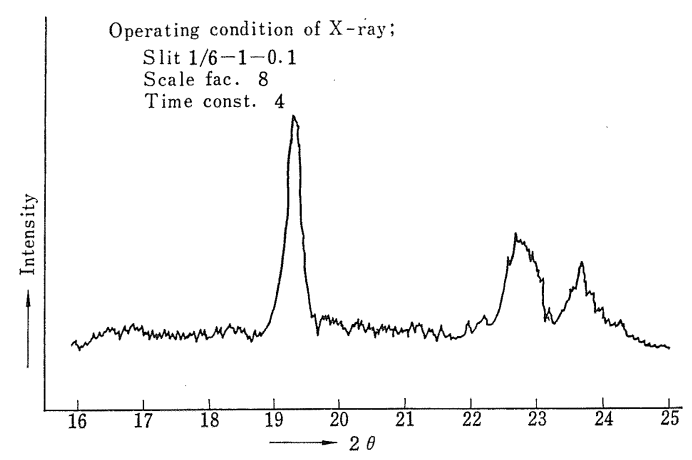

Fig.-4 X-ray diffraction pattern of tallow $(\beta)$.

$\beta$ 型 牛脂を石油エーテルより $-20^{\circ} \mathrm{C}$ で結晶させる。 これらの結晶型のX線回折図を Fig. 1 4 亿示す。 $\alpha$ 型の特徴的な回折線は， $4.14 \AA\left(2 \theta=21.4^{\circ}\right)$ に現わ れる。牛脂の $\alpha$ 型は急冷により生成するが室温に放置す ると, $\beta^{\prime}$ 型に転移して行く。

$\beta^{\prime}$ 型の特徵的な回折線は, $3.83 \AA\left(2 \theta=23.2^{\circ}\right)$ 付近と $4.20 \AA\left(2 \theta=21.0^{\circ}\right)$ 付近に現われる。牛脂の $\beta^{\prime}$ 型は, 徐冷放置によって容易に生成し, しか子室温 $20^{\circ} \mathrm{C}$ 付近 の放置の状態では，2，3 力月間は安定と思われる。

牛脂の intermediate 型の特徵的な回折線は, ばく然と してはいるが, $3.83 \AA$ 付近に弱いピーク，4.32 $(2 \theta$ $\left.=20.5^{\circ}\right), 4.46 \AA\left(2 \theta=19.9^{\circ}\right), 4.60 \AA\left(2 \theta=19.3^{\circ}\right)$ 付近 の三つに弱いピークが認められた。これら intermediate 
型の短面間隔は，Hoerr の記載（5）と少し相違し，ま た明確ではないが，その原因は，測定温度の $20^{\circ} \mathrm{C}$ 付近 に㧍けるネツ和牛脂中の液状油が，回折を妨害している のではないかと思われる。牛脂の intermediate 型は, 機械的な練りを加え $30^{\circ} \mathrm{C}$ 程度でテンパリングを行なう ことにより生成するが， $\beta$ 型に移行しにくく，この結晶 で安定であるようにみえる (4)。

$\beta$ 型の特徵的な回折線は，4.60 $\AA\left(2 \theta=19.3^{\circ}\right)$ 亿強い ピークが現われる。 $\beta$ 型は，牛脂を石油エーテルより結 晶させることにより生成する。

\section{$3 \cdot 2$ カカオ脂系油脂の結晶構造}

カカオ脂, シア脂, パーム油など, 2-不飽和-1, 3-飽 和トリグリセリドの含有量の多、油脂の $\mathrm{X}$ 線回折図を Fig.5 7 に示す。これらの油脂は，その短面間隔が示 すように安定な $\beta$ 型結晶構造をとっている。これは $\beta$ 型 をとりやすいグリセリド，S-O-P, S-O-S などが主成分 であるために転移速度がきわめて速く，この型で現われ る。

\section{3 可塑性油脂の結晶転移}

つぎに可塑性油脂の成分とその結晶転移の難易との関

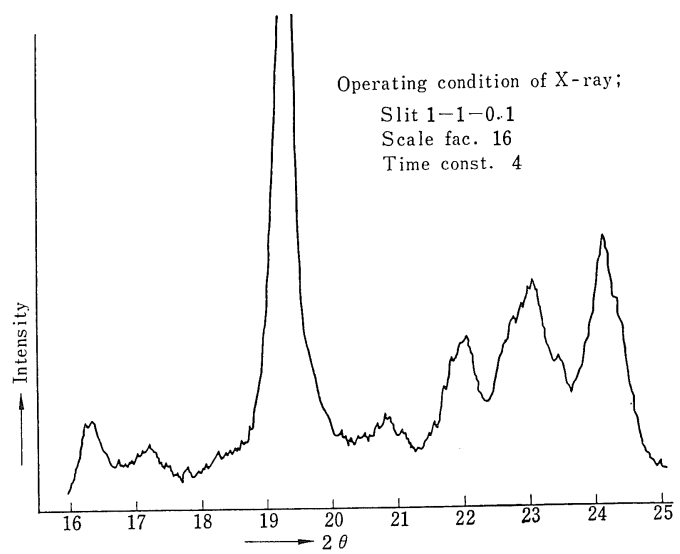

Fig.-5 X-ray diffraction pattern of cocoa butter.

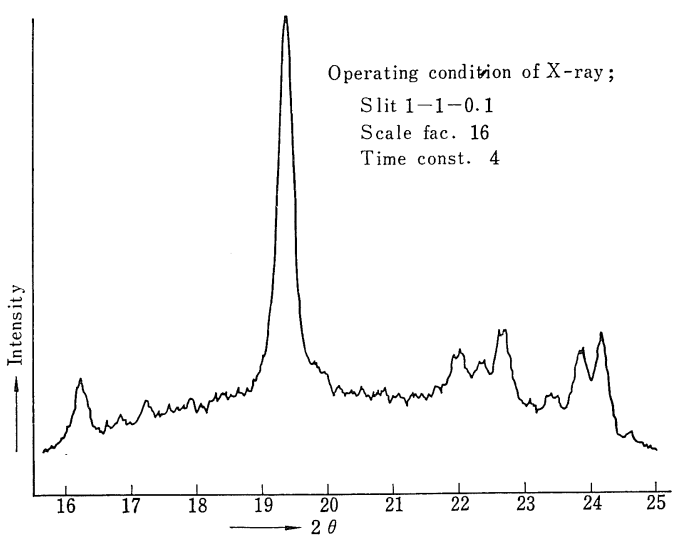

Fig,-6 X-ray diffraction pattern of shea butter.

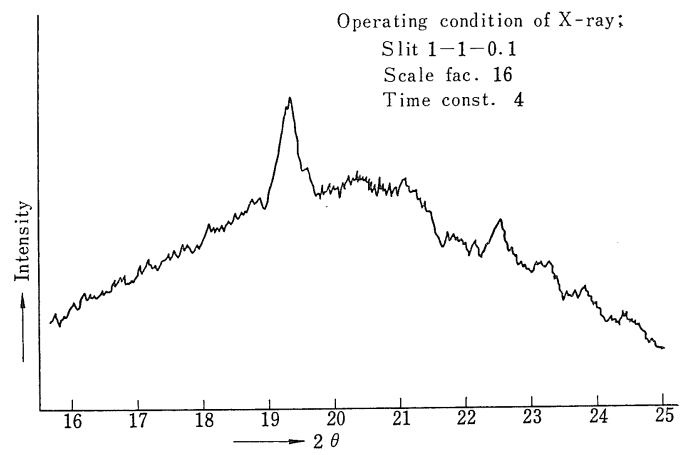

Fig.-7 X-ray diffraction pattern of palm oil. 連を調べる目的で一つのモデル実験を行なった。すなわ ち牛脂および軟質硬化油の 2 成分を選び，両者を各割合 に配合して可塑性油脂を作り，そのネッ和操作後のテン パリング温度による結晶型の転移速度を測定した。

原料として使用した牛脂および軟質硬化魚油の性状は つぎのとおりである。

Table-3 Physical properties of tallow and hydrogenated fish oil.

\begin{tabular}{l|c|c|c}
\hline & I.V. & $\mathrm{mp}\left({ }^{\circ} \mathrm{C}\right)$ & $\mathrm{S} . \mathrm{V}$. \\
\hline Tallow & 45.5 & 42 & 195 \\
\hline $\begin{array}{l}\text { Hydrogenated } \\
\text { fish oil }\end{array}$ & 72.4 & 32 & 187 \\
\hline
\end{tabular}

上の原料油からつぎの配合油を調製して使用した。

Table-4 Blended ratio of tallow (T) and hydrogenated fish oil (H.F.).

\begin{tabular}{|c|c|c|c|c|c|c|}
\hline \multirow{2}{*}{$\begin{array}{r}\text { Ratio } \\
(\%)\end{array}$} & T. H.F & T. H.F & T. H.F & T. H.F & T. H.F & T. H.F. \\
\hline & $100 \quad 0$ & $80 \quad 20$ & $70 \quad 30$ & $50 \quad 50$ & $30 \quad 70$ & $\begin{array}{ll}0 & 100\end{array}$ \\
\hline I.V.* & 45.5 & 48.5 & 50.7 & 56.3 & 63.0 & 72.4 \\
\hline
\end{tabular}

* I.V.; Found value

X線測定に際しての外部雾囲気の温度は，おのおのの 配合油に対してつぎのようにコントロールを行なった。

Table-5 Measuring temperature of sample in the $\mathrm{X}$-ray diffraction.

\begin{tabular}{c|r|c}
\hline \multicolumn{2}{c|}{ Ratio $(\%)$} & Measuring temp. $\left({ }^{\circ} \mathrm{C}\right)$ \\
\cline { 1 - 2 } T. & H.F. & \\
\hline 100 & 0 & $24 \pm 1$ \\
80 & 20 & $24 \pm 1$ \\
70 & 30 & $24 \pm 1$ \\
50 & 50 & $24 \pm 1$ \\
30 & 70 & $24 \pm 1$ \\
0 & 100 & $20 \pm 1$
\end{tabular}

繰り返しによる回折強度の再現性は実験条件を同一に した場合ほとんど同じ強度を示し再現性を確認した。

$\beta^{\prime}$ 型より intermediate 型結晶構造への転移率の算出 に際してはつぎのよらに行なった。 
おのおのの組成の配合油より室温 $20^{\circ} \mathrm{C}$ 付近に徐冷一 昼夜放置して $\beta^{\prime}$ 型結晶を生成させる。一方,ネッ和後 30 ${ }^{\circ} \mathrm{C}$ にて一週間以上テンパリングを行ない intermediate 型結晶を生成させる。おのおのを Table-4 の割合に配 合し，すみやかにX線測定を行なう。

回折図より $\beta^{\prime}$ 型結晶に特徵的な $3.83 \AA$ 付近に現わ

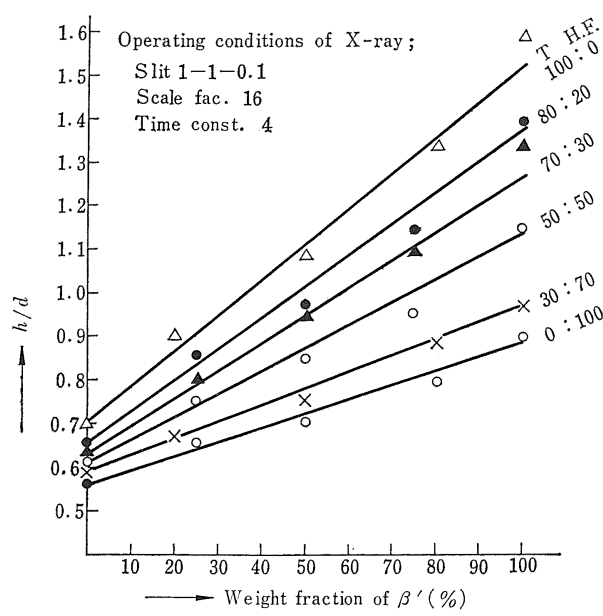

Fig.-8 Intensity calibration curve for the ratio of $\beta^{\prime}$-intermediate form.

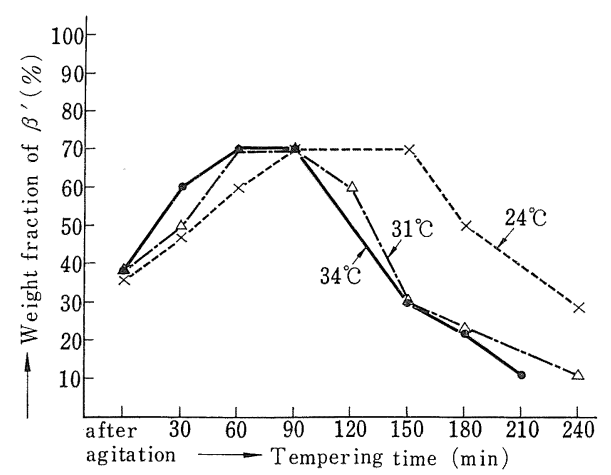

Fig.-9 Transformation of crystal form tallow.

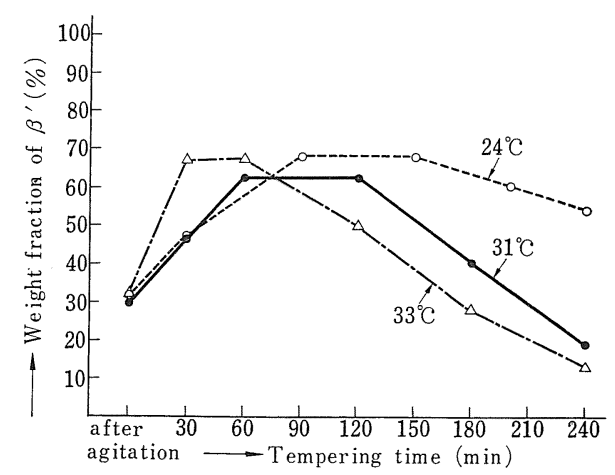

Fig.-10 Transformation of crystal form of blended fats (tallow $80 \%$, H.F. 20\%).
れる回折線の “ピークの基底までの高さ/ピークの基底 幅 $2 \mathrm{~cm} "(h / d, d=2)$ を求め， $\beta^{\prime}$ 型結晶の割合を横軸 に，h/d を縦軸にプロットして検量線を作成する。

検量線は Fig。-8 に表わした。

この検量線を基にし，実測して得られた可塑性油脂の 短面間隔の強度から $\beta^{\prime}$ 型結晶の含有量を求めて, $\beta^{\prime} \rightarrow$ intermediate 型への転移率を算出した。

つぎに配合とテンパリング温度による結晶転移の様子

を Fig.9〜16 に示した。

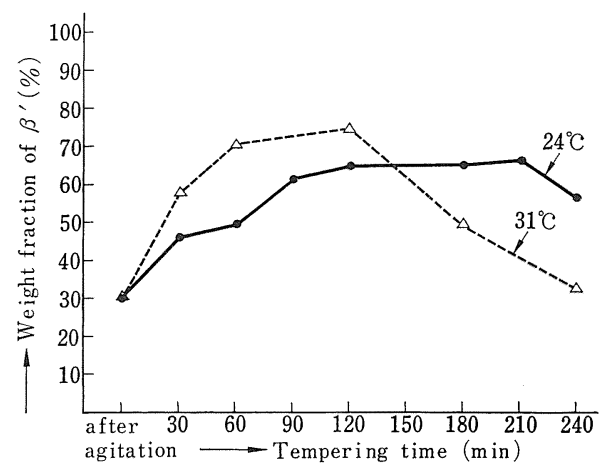

Fig.-11 Transformation of crystal form of blended fats (tallow 70\%, H.F. 30\%).

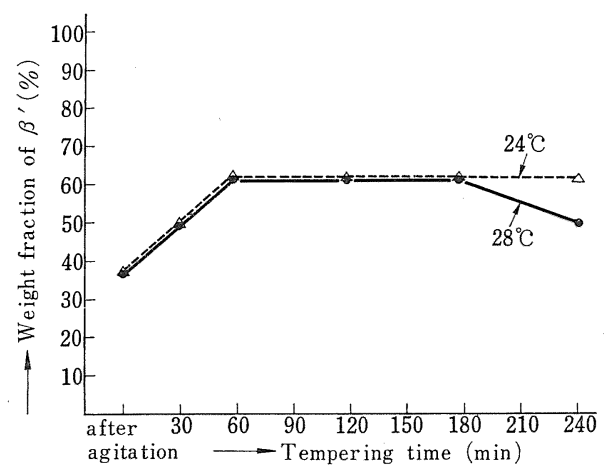

Fig.-12 Transformation of crystal form of blended fats (tallow 50\%, H.F. 50\%).

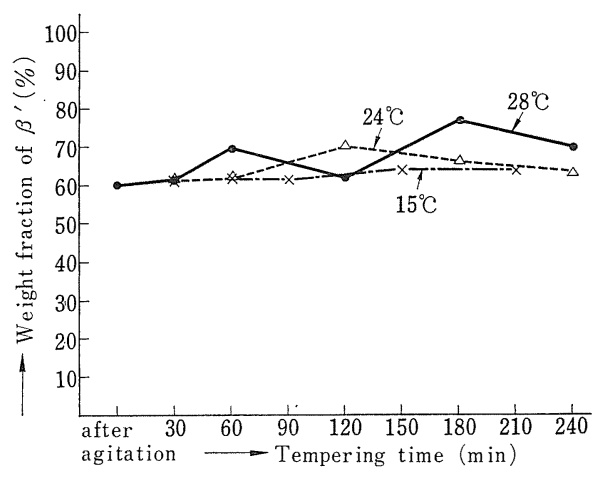

Fig.-13 Transformation of crystal form of blended fats (tallow 30\%, H.F. 70\%). 
これらの実験結果よりつぎの事実が判明した。

1） Fig.-9 より牛脂 $100 \%$ 可塑性油脂は $\beta^{\prime}$ 型より intermediate 型への転移が速く,テンパリング温度 $31^{\circ} \mathrm{C}$ においては，240 min 程度でほとんど転移を完了してし まう。

2） Fig.-13 より軟質硬化魚油 70\% 配合可塑性油脂 は，240 min 以内において結晶転移がみられない。

3) Fig.-14より軟質硬化魚油は，240 min 以内では intermediate 型への転移はまだ起こっていない。

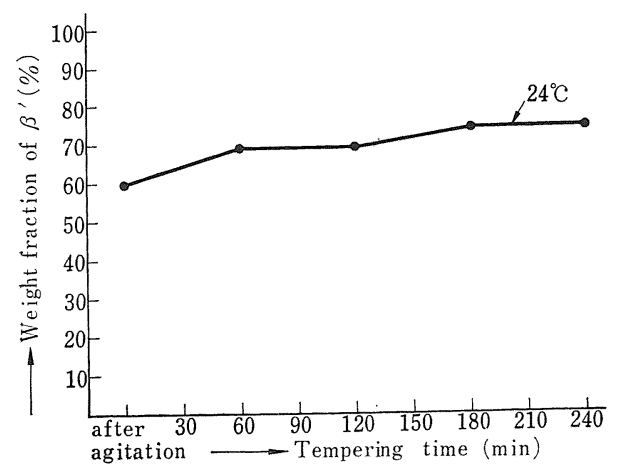

Fig.-14 Transformation of crystal form of H.F.

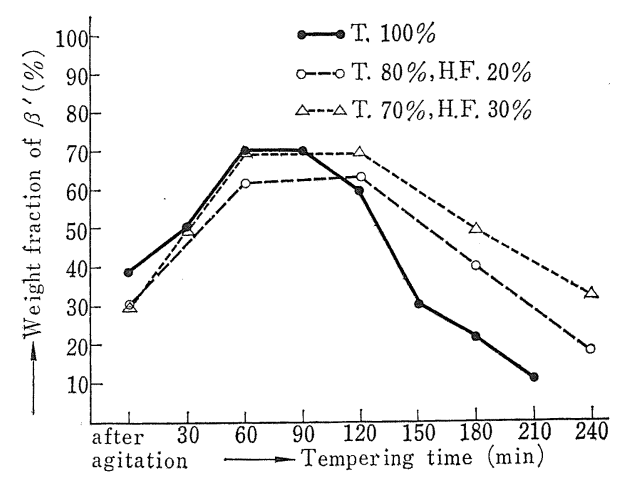

Fig.-15 Transformation of crystal form of blended fats tempering at $31^{\circ} \mathrm{C}$.

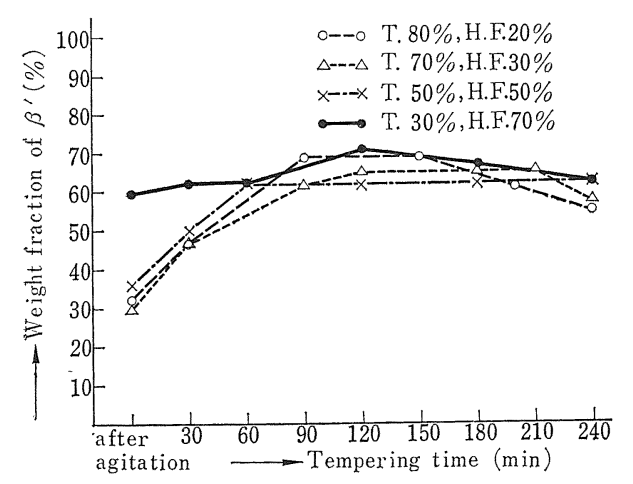

Fig.-16 Transformation of crystal form of blended fats tempering at $24^{\circ} \mathrm{C}$.
4) Fig。-15 より $31^{\circ} \mathrm{C}$ テンパリングの条件下では, 軟質硬化魚油の含有量が $30 \%$ 程度含まれていてもかな りすみやかに intermediate 型への移行が起こる。

5） Fig.-16 より $24^{\circ} \mathrm{C}$ テンパリングの条件下では軟 質硬化魚油含有量が 20 70\% の配合油において $\beta^{\prime}$ 型 より intermediate 型への結晶転移は遅く著しい相違が みられない。

6） Fig.-10より軟質硬化魚油含有量が $20 \%$ の配合

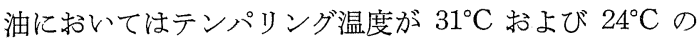
間では結晶転移がかなり相違する。

7） Fig.-14 より軟質硬化魚油含有量が $50 \%$ になる とテンパリング温度の影響が少なくなる。

8）全部の配合油を通じてテンパリング温度が高いほ ど結晶の転移速度も大きくなるが，テンパリング温度は 油脂の融点に制約される。

9）各グラフを通じて $\beta^{\prime}$ 型含有量が最高 $70 \%$ 程度 になっているが，検量線に対する相対的な值であり，実 際は $70 \%$ 付近で $\beta^{\prime}$ 型に近いものと思われる。

以上の点から, 軟質硬化魚油の含有量がふえるにつれ て， $\beta^{\prime}$ 型より intermediate 型への結晶転移が遅くなる ことがわかる。ただし硬化油であってもネツ和後 $25^{\circ} \mathrm{C}$ 程度に 30 日ほどテンパリングを続けると intermediate 型に近い結晶構造がみられた。

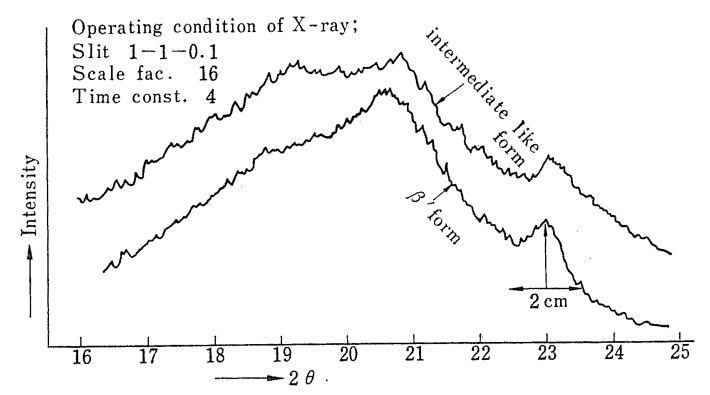

Fig.-17 X-ray diffraction pattern of hydrogenated fish oil.

\section{$3 \cdot 4$ カカオ脂の結晶転移}

カカオ脂については $\mathrm{X}$ 線回折図を記載した報文 ${ }^{15)}$ 見 られるが, 著者らはカカオ脂の結晶転移について実験を 行なった。カカオ脂系油脂は,非常にすみやかに $\beta$ 型結晶 へ転移し， $\beta$ 型回折線ピーク 明確であるので本実験に おける転移率の算出には， $\beta$ 型の特徵である短面間隔 $4.60 \AA\left(19.3^{\circ}\right)$ の回折線ピークの高さの比，すなわち基 底幅 $1.5 \mathrm{~cm}$ に至る高さを求め, これを縦軸にとって $\beta$ 型含量に対しプロットして Fig.-18 に示す関係を得た。 カカオ脂の結晶転移の測定はつぎのようにして行なっ た。カカオ脂をいったん $60^{\circ} \mathrm{C}$ 程度に加温融解し, 一方 試料板を氷水で泠却しつつ, 試料板上に少しずつ流し达 む。充分に急冷され固まった時点で X 線測定を行な 


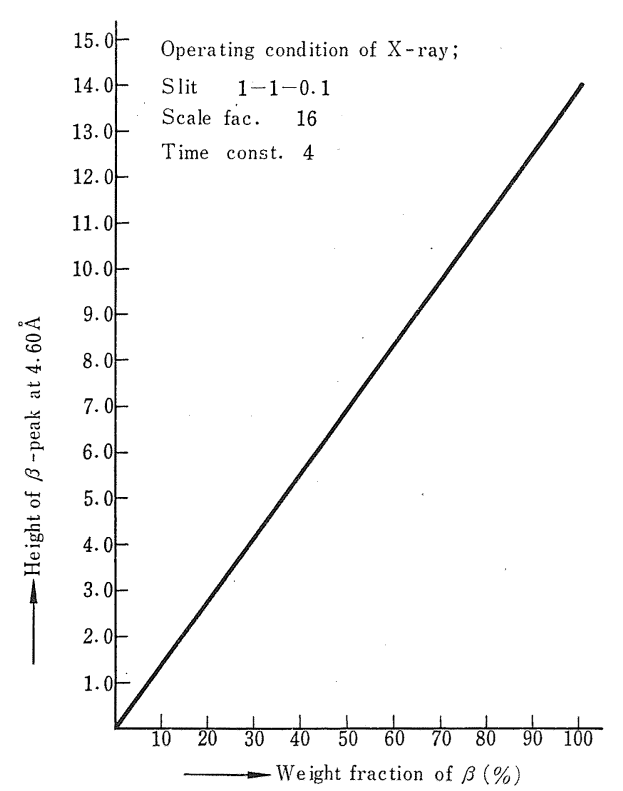

Fig.-18 Calibration curve for the ratio of $\beta$ form.

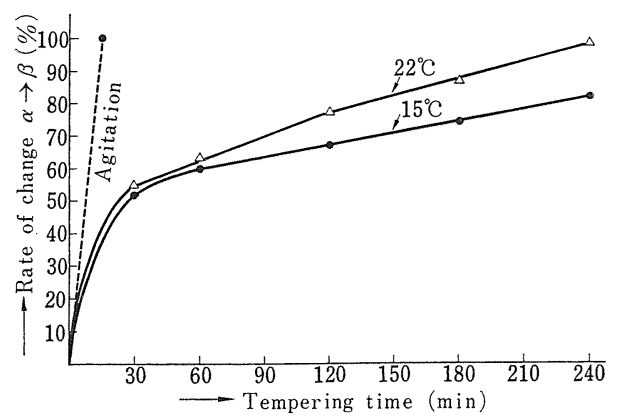

Fig.-19 Transformation of crystal form of cocoa butter.

う。また試料板を一定温度に放置しながら，各時間おき にX線測定を行なら。これより求めたカカオ脂の結晶転 移について Fig.-19 にグラフ化し, 結晶転移の様子を

Fig.-20 に示した。

この実験の結果, カカオ脂の結晶転移がきわめて短時 間のらちに起こることが認められた。

\section{4 考察}

グリセリドの結晶型の判別は複雑なる組成を有する油 脂においても確認することができる。すなおち， $\alpha$ 型結 晶構造は, $4.14 \AA$ 付近に特徴的な回折線を有し, $\beta^{\prime}$ 型 は, $3.83 \AA, 4.20 \AA$ 付近に 2 本の回折線， $\beta$ 型は 4.60 $\AA$ 付近に特徵的な回折線が現われる。また intermediate 型結晶構造は, $3.8 \AA$ 付近に弱いピーク, $4.20 \AA$ 只 4.70 Åにたる幅広い回折線の山の変化で判別される。

牛脂, 硬化油系の intermediate 体が明確になってい ないのはこれらの油脂中の液状油が回折線に影響を与

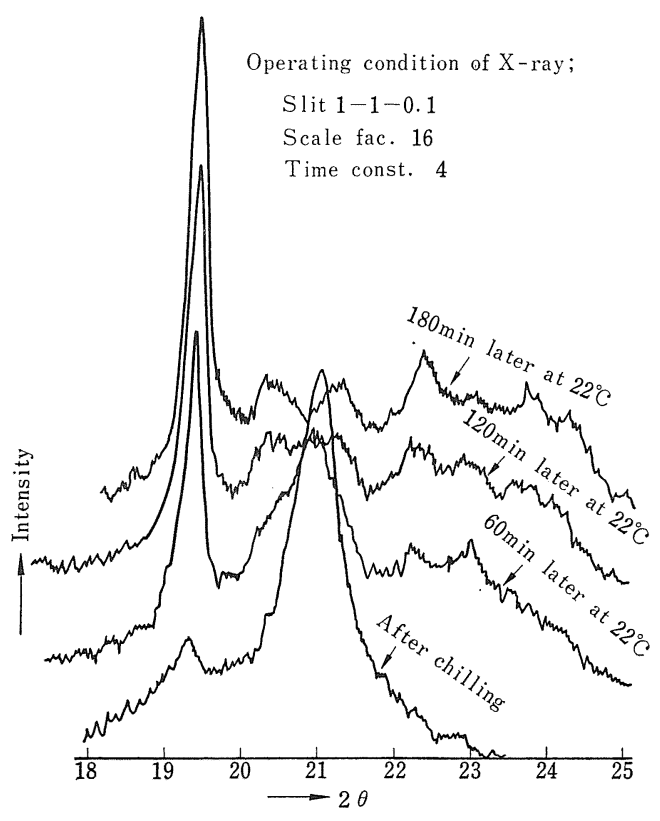

Fig.-20 Change in X-ray diffraction pattern of cocoa butter.

えているものと思われる。複雑なるグリセリド組成を有 する油脂の結晶が，どのように転移して行くか定量的に 取り扱うことはむずかしい。特に広い融点範囲のグリ セリドを含む可塑性油脂の転移について正確に定量を行 なうことは不可能に近い問題であるが，その一つの試み として, 牛脂, 硬化魚油系油脂が, $\beta^{\prime}$ 型から intermediate 型結晶構造をとることから， $\beta^{\prime}$ 型結晶構造に特徵 的な回折線に注目して, ピークの相対的な高さの比較に よって,だいたいの結晶転移について求めた。牛脂, 軟 質硬化魚油系可塑性油脂は, その配合割合によって転移 速度が相違するが，一般に機械的な練り(ネッ和)を行な えば, テンパリングによって $\beta^{\prime}$ 型結晶より intermediate 型結晶へ転移することが判明した。しかし練りを行なっ ていない可塑性油脂は, 著者らの実験の結果, $\beta^{\prime}$ 型の 状態で数力月間は安定になっているようである。一般に ショートニング類は, $\beta^{\prime}$ 型あるいは, intermediate 型 結晶構造をとり ${ }^{4)}, \beta$ 型結晶構造をとりうるような配合 は望ましくないものと思われる。

ショートニング中に $\beta$ 型結晶が生成すると, 米粒程度 の粒状物となって現われる。著者らは, 実験室的に, 牛 脂と植物油の配合によるショートニングを調製し数カ月 間放置して粒状物を発生させてその X 線回折図をとっ た。

その結果, Fig.-21 に明らかなように $\beta$ 型結晶構造で あることがわかった。

カカオ脂系油脂の場合は, S-O-P, S-O-S などのト リグリセリドを主体とした単純な成分組成であるため, 結晶転移の定量的な取扱いは簡単である。各単一トリ 


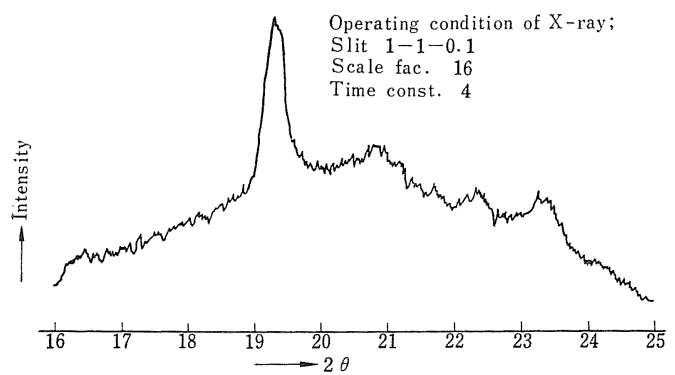

Fig.-21 X-ray diffraction pattern of granular part growed in plastic fats.

グリセリドは，それ自身の安定な結晶構造が存在する が，他のトリグリセリドを混入すると転移速度に変化を きたしてくる。この問題については現在検討中である。 グリセリドの転移の問題はさらに詳細なる実験が必要で ある。

最後に本論文の発表を許可された 鐘淵化学工業株式会社 中司 社長ほか関係各位に深く感謝いたします。
文献

1) E.S. Lutton, J. Am. Chem. Soc., 68, 676 (1946)

2) E.S. Lutton, J. Am. Chem. Soc., 70, 248 (1948)

3) T. Malkin, J. Chem. Soc., 1949, 369

4) C.W. Hoerr, J. Am. Oil Chemists' Soc., 37, 539 (1960)

5) C.W. Hoerr, J. Am. Oil Chemists' Soc., 41 (7), p. $4,22,32,34$, (1964)

6) C.E. Clarkson, J. Chem. Soc., 1934, 666

7) T. Malkin, J. Chem. Soc., 1939,103, 577

8) T. Malkin, J. Chem. Soc., 1949, 369

9) E.S. Lutton, J. Am. Chem. Soc., 70, 2441 (1948)

10) E.S. Lutton, J. Am. Chem. Soc., 68, 676 (1946)

11) F.D. Gunstone, Chem. and Ind., 42, 84 (1964)

12) D.R. Marker, J. Am. Oil Chemists' Soc., 35, 130 (1958)

13) H. Lars Wiederman, J. Am. Oil Chemists' Soc., 38, 389 (1961)

14）寺田ら, 油化学, 11, 400 (1962)

15) R.O. Feuge, J. Am. Oil Chemists' Soc., 39, 310 (1962)

（昭和 40 年 5 月 21 日受理）

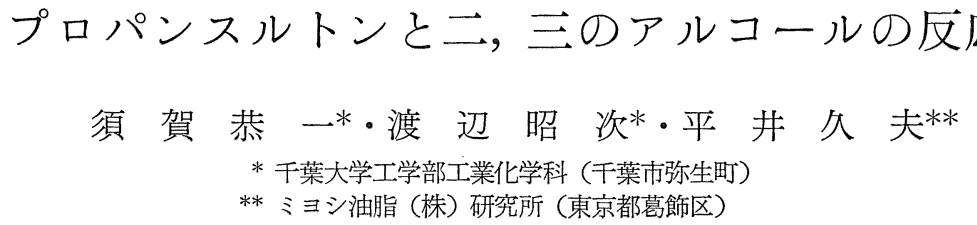

\author{
Reaction of Propane Sultone with Alcohols \\ Kyōichi Suga, Shōji Watanabe* and Hisao HiraI** \\ * Department of Applied Chemistry, Faculty of Engineering, \\ Chiba University (Yayoichō, Chiba-shi) \\ ** Miyoshi Oil \& Fat Co., Ltd. (Katsushika-ku, Tokyo)
}

Sodium (or potassium) alkoxy propane sulfonates were prepared from alcohols, which were mainly terpenic alcohols, and propane sultone. Sodium decyloxy propane sulfonate showed a properties for surface active agents, but those from terpenic alcohols did not show the properties.

\section{1 緒言}

プロパンスルトン（I） は非常に反応性に富む化合物 で, 活性水素を持つアルコール，酸, アミン, メルカプ タンなどと容易に反応し，界面活性剂，染料などの分野 においてきわめて重要な応用がすでに知られている ${ }^{1), 2) 。 ~}$ 著者らはテルペン系アルコールを中心とした種々のアル コールと（I）からのアルコキシプロパンスルホン酸ナ トリウムおよびカリウム (II)の合成法について検討し， また得られた（II）の界面活性戍としての性能，その他
の性状について検討した結果を報告する。

$$
2 \text { 実験 }
$$

\section{$2 \cdot 1$ 試料}

プロパンスルトン (I) は Shell 石油（株）製のもの を減圧蒸留し， bp 134 $135^{\circ} \mathrm{C} / 3 \mathrm{~mm} \mathrm{Hg}$ の留分を用い た。テルペンアルコール類は高砂香料工業（株）製のも のを，そのほかは市販品をそれぞれ蒸留して使用した。

$2 \cdot 2$ シトロネロールとプロパンスルトン（I）の反応 窒素ガス気流下，シトロネロール $41.2 \mathrm{~g}$, 金属ナト 